\title{
TITLE:
}

\section{Cells immobilized on patterns printed in DNA by an inkjet printer.}

$\operatorname{AUTHOR}(S):$

Sakurai, Kengo; Teramura, Yuji; Iwata, Hiroo

\section{CITATION:}

Sakurai, Kengo ...[et al]. Cells immobilized on patterns printed in DNA by an inkjet printer.. Biomaterials 2011, 32(14): 3596-3602

ISSUE DATE:

2011-05

URL:

http://hdl.handle.net/2433/139528

\section{RIGHT:}

(C) 2011 Elsevier Ltd.; This is not the published version. Please cite only the published version.; この論文は出版社版でありません。引用の際に は出版社版をご確認ご利用ください。 


\section{Cells immobilized on patterns printed in DNA by an inkjet printer}

Kengo Sakurai $^{\mathrm{a}}$, Yuji Teramura ${ }^{\mathrm{b}}$, Hiroo Iwata ${ }^{\mathrm{a}}$

${ }^{a}$ Department of Reparative Materials, Institute for Frontier Medical Sciences, Kyoto

University, 53 Kawara-Cho, Shogoin, Sakyo-Ku, Kyoto, 606-8507, Japan

${ }^{\mathrm{b}}$ Radioisotope Research Center, Kyoto University, Yoshida-Konoe-Cho, Sakyo-ku, Kyoto, 606-8501, Japan

* Address correspondence and reprint requests to Hiroo Iwata, Ph.D.

E-mail: iwata@frontier.kyoto-u.ac.jp, PHONE/FAX: +81-75-751-4119

Keywords: Cell adhesion; DNA; Surface modification; Gold; Biocompatibility 


\section{Abstract}

The ability to two-dimensionally align various kinds of cells freely onto substrate would be a useful tool for analysis of cell-cell interactions. In this study, we aimed to establish a method for attaching cells to the substrate in which the pattern is drawn by an inkjet printer. Poly-deoxyribonucleic acid (DNA) was immobilized onto the cell surface by use of DNA-conjugated poly(ethylene) glycol-phospholipid (DNA-PEG-lipid), which is the amphiphilic conjugate of PEG-lipid and single-stranded DNA. The surface of the substrate was then modified with the complementary DNA using an inkjet printer. Finally, DNA-immobilized cells were attached onto the substrate through DNA hybridization. The use of the inkjet printer enabled us to draw the DNA pattern accurately on the substrate with a resolution of a few hundred micrometers. DNA-immobilized cells could be attached precisely along the DNA pattern on the substrate. In addition, various kinds of cells could be attached simultaneously by using various sequences of DNA. Our technique is promising for analysis of cell-cell interactions and differentiation induction in stem cell research. 


\section{Introduction}

Many types of cell arrays have been developed for use in various biomedical studies, such as drug screening in the pharmaceutical industry [1], high-throughput assays in functional analyses of genes [2,3], and analysis of cell-cell interactions in regenerative medicine [4]. Cells must be immobilized onto specific areas on a plate for preparation of a cell array, and various kinds of molecules have been examined as adhesives for immobilization of cells on the surface. Cell adhesive glycoproteins, such as fibronectin and vitronectin, have been preferentially used in these studies $[5,6]$. Patterning of these proteins onto a substrate has been achieved using micro-contact printing methods and photolithography $[7,8]$. Various patterns can be drawn with cells using these methods, but only one kind of cell has been immobilized in most studies. Tedious work is required to immobilize two or more kinds of cells on a plate with complex patterns. Antibodies against membrane proteins can be used to immobilize different kinds of cells onto specific areas of a plate [9], but they are expensive and finding suitable antibodies can be difficult.

In a previous study, we introduced DNA as the adhesive molecule and prepared cell arrays using the combination of DNA and photolithography [10]. Although cells could be immobilized in various patterns and two kinds of cells could be immobilized 
on a plate without difficulty using two kinds of DNA with different sequences, photolithography is not sufficiently flexible to draw complicated patterns and is also time consuming.

In this study, we employed an inkjet printer to draw various patterns using DNA molecules carrying a thiol group at the 5' end (DNA-SHs) as inks on a glass plate with a gold thin layer. DNA', with a sequence complementary to the DNA on the plate, was introduced onto the cell surface using polyethylene glycol-conjugated phospholipid (PEG-lipid) derivatives [10-12]. The cells were applied to the plate and immobilized there through DNA hybridization. 


\section{Materials and methods}

\section{Materials}

$\alpha$-N-hydroxysuccinimidyl- $\omega$-maleimidyl poly(ethylene glycol) (NHS-PEG-Mal, MW:5000) and 1,2-dipalmitoyl-sn-glycerol-3-phosphatidylethanolamine (DPPE) were purchased from NOF Corporation (Tokyo, Japan). Dichloromethane, chloroform, diethyl ether, dimethyl sulfoxide (DMSO), triethylamine (TEA), and penicillin-streptomycin mixed solution were purchased from Nacalai Tesque (Kyoto, Japan). Fetal bovine serum (FBS) was purchased from BioWest (Miami, FL) and phosphate-buffered saline (PBS) from Nissui Pharmaceutical, Co., Ltd (Tokyo, Japan). Hanks' balanced salt solution and RPMI 1640 medium were purchased from Invitrogen (Carlsbad, CA, USA). Bovine serum albumin (BSA), PKH26 Red Fluorescent Cell Linker Kit, PKH67 Green Fluorescent Cell Linker Kit, L- $\alpha$-phosphatidylcholine from egg yolk, Type XVI-E (EggPC), poly(adenosine phosphate) (20) (polyA20) and poly(thymidine phosphate) (20) (polyT20) carrying the SH group protected with 6-hydroxy-1-hexanethiol at the 5'-end (DNA-SH), and DNAs carrying fluorescein isothiocyanate (FITC) at the 5'-end were purchased from Sigma-Aldrich Chemical Co. (St. Louis, MO, USA). SeqA, SeqA', SeqB, and SeqB' listed in Table 1 were also purchased from Sigma-Aldrich Chemical. Cover glasses $(22 \times 26 \mathrm{~mm}, 0.12-0.17 \mathrm{~mm}$ 
thickness) and glass plates (BK7, refractive index: 1.515 , size: $25 \times 25 \times 1 \mathrm{~mm}$ ) were purchased from Matsunami Glass Ind., Ltd (Osaka, Japan) and Arteglass Associates Co. (Kyoto, Japan), respectively. Nitrocellulose membrane (pore size: $0.8 \mu \mathrm{m}$ ), a Millex-GP $0.22 \mu \mathrm{m}$ Filter Unit, and an Isopore Membrane Filter $(0.1 \mu \mathrm{m})$ were purchased from Millipore Co. (MA, USA). The phospholipid C test was purchased from Wako Pure Chemical Industries (Osaka, Japan).

Synthesis of DNA-PEG-lipid

DNAs with a 5'-end SH group were prepared by reduction of the disulfide bond at the 5' end with dithiothreitol according to the manufacturer's instructions. DNA-conjugated PEG-phospholipid (DNA-PEG-lipid) was prepared from DNA-SH and maleimide-PEG-lipid (Mal-PEG-lipid) as previously reported [10, 13]. Briefly, a Mal-PEG-lipid solution $(270 \mu \mathrm{L}, 1 \mathrm{mg} / \mathrm{mL}$ in PBS) and a DNA-SH solution (180 $\mu \mathrm{L}$, $300 \mu \mathrm{g} / \mathrm{mL}$ in PBS) were mixed in PBS for $12 \mathrm{~h}$ at RT to prepare DNA-PEG-lipids. DNA-PEG-lipids were used unrefined. In this study, three combinations of complementary DNAs, polyA20/polyT20, SeqA/SeqA', and SeqB/SeqB', were used (Table 1). 
Preparation of liposome modified with polyT20-PEG-lipid

EggPC (20 mg) was dissolved in chloroform $(2 \mathrm{~mL})$. The Egg PC solution in

chloroform was evaporated to prepare a dry thin lipid film using a rotary evaporator.

One milliliter of PBS was added to the lipid film and stirred vigorously at $4^{\circ} \mathrm{C}$ for $1 \mathrm{~d}$ to prepare lipid vesicles (lipid concentration $=10 \mathrm{mg} / \mathrm{mL}$ ). The suspension was then extruded through a series of membrane filters with a pore size $0.8 \mu \mathrm{m}, 0.22 \mu \mathrm{m}(2$ times), and $0.1 \mu \mathrm{m}$ (10 times) to form small unilamellar vesicles or liposomes ( 100 nm diameter). Lipid concentration was determined using the phospholipid $\mathrm{C}$ test kit. A polyT20-PEG-liposome complex was prepared by incubation of a mixture of a liposome suspension $(500 \mu \mathrm{L}$ of $8 \mathrm{mg} / \mathrm{mL})$ and DNA-PEG-lipid solution $(40 \mu \mathrm{L}$ of $500 \mu \mathrm{g} / \mathrm{mL})$ at $37^{\circ} \mathrm{C}$ for $60 \mathrm{~min}$.

Immobilization of DNA on a glass plate

Several patterns were printed with DNA-SHs on glass plates with a gold thin film by using an inkjet printer, as shown in Scheme 1. Cover glasses were immersed in a piranha solution (a 7:3 mixture of concentrated sulfuric acid and 30\% hydrogen peroxide) for $10 \mathrm{~min}$, washed three times with deionized water, and rinsed three times with Milli-Q water and three times with 2-propanol. The cover glasses were mounted on 
a rotating stage of a thermal evaporation coating apparatus (V-KS200, Osaka Vacuum, Ltd., Osaka, Japan) and coated with a 1-nm chromium layer and then a 19-nm gold layer. A solution of DNA-SHs (300 $\mu \mathrm{g} / \mathrm{mL}$ in PBS) was applied to a cartridge and then printed onto a gold surface by an inkjet printer (PIXUS-iP4700, Canon, Tokyo, Japan), which was controlled by Microsoft PowerPoint. The plates were left under ambient conditions for $60 \mathrm{~min}$ to form a thiol-gold linkage and then washed with distilled water.

\section{Surface analyses}

To examine DNA immobilization, contact angles and infrared absorption spectra were determined by a contact angle meter (CA-X, Kyowa Interface Science Co. Ltd., Saitama, Japan) and by a Fourier-transform infrared spectrometer (FTIR) (Spectrum One, Perkin Elmer, MA, USA) equipped with a reflection absorption spectrometer (RAS) (Spectrum One, Perkin Elmer, MA, USA). The contact angles on each substrate were determined by the sessile drop method, and averages for four measurements were used. For FTIR-RAS measurement, the glass plate coated with $\mathrm{Cr}(1 \mathrm{~nm}) / \mathrm{Au}(199 \mathrm{~nm})$ was used for immobilization of DNA-SH. 
Interactions between polyT20-PEG-liposome and polyA20 on a surface were examined using a lab-made surface plasmon resonance (SPR) apparatus [14]. A flow chamber was prepared by placing a gold-covered glass plate (a 1-nm chromium layer and a 49-nm gold layer) on the prism of the SPR apparatus, and PBS was circulated at a flow rate of $4.0 \mathrm{~mL} / \mathrm{min}$ in the flow chamber for at least $5 \mathrm{~min}$. A solution of polyA20-SH solution $(50 \mu \mathrm{g} / \mathrm{mL}$ in PBS) was introduced into the flow chamber and allowed to immobilize onto the gold surface for $60 \mathrm{~min}$ through the thiol-gold reaction. Then, the surface was washed with PBS and exposed to a BSA solution $(10 \mathrm{mg} / \mathrm{mL}$ in PBS) for $20 \mathrm{~min}$ to inhibit nonspecific adsorption of the liposome. After a wash with PBS, the polyT20-PEG-liposome suspension ( $5 \mu \mathrm{g} / \mathrm{mL}$ in PBS) was circulated for more than 60 min. A polyA20 immobilized surface that had been pretreated with a polyT20 solution was also exposed to the polyT20-PEG-liposome to examine immobilization of the polyT20-PEG-liposome on the surface through the hybridization between polyA20 and polyT20.

Cell surface modification with DNA-PEG-lipid

CCRF-CEM cells, a human T cell lymphoblast-like cell line, were obtained from the Health Science Research Resources Bank (Osaka, Japan). A suspension culture of 
CCRF-CEM cells was made in RPMI-1640 medium supplemented with 10\% FBS, 100

$\mathrm{U} / \mathrm{mL}$ penicillin, and $100 \mu \mathrm{g} / \mathrm{mL}$ streptomycin at $37^{\circ} \mathrm{C}$ under $5 \% \mathrm{CO}_{2}$. CCRF-CEM cells $\left(5 \times 10^{6}\right.$ cells $)$ were washed twice with PBS by centrifugation $\left(180 \times g, 5 \mathrm{~min}, 25^{\circ} \mathrm{C}\right)$.

Cells were then labeled with PKH red or PKH green according to the manufacturer's instructions for observation under a fluorescence microscope. A total of $60 \mu \mathrm{L}$ of a DNA-PEG-lipid solution ( $500 \mu \mathrm{g} / \mathrm{mL}$ in PBS) was added to $60 \mu \mathrm{L}$ of a cell suspension $\left(8.3 \times 10^{7}\right.$ cells $\left./ \mathrm{mL}\right)$ and incubated for $90 \mathrm{~min}$ at $\mathrm{RT}$ with gentle agitation. The cells were suspended in $3 \mathrm{~mL}$ PBS and washed with PBS by centrifugation $\left(180 \times g, 5 \mathrm{~min}, 25^{\circ} \mathrm{C}\right)$. The washing procedure was repeated twice. Cells modified with DNA-PEG-lipid were designated as DNA-PEG-cells.

Immobilization DNA-PEG-cells on substrate

Silicone slices ( $2 \mathrm{~cm}$ in length $1 \mathrm{~mm}$ in thickness) were placed on a glass plate with a DNA-SH pattern, and a cover glass was then placed on the slices to create a space $1 \mathrm{~mm}$ thick between the two glass plates. A BSA solution $(200 \mu \mathrm{L}, 10 \mathrm{mg} / \mathrm{mL})$ was applied to the space to block the area on the glass plate without polyA20-SH. After a wash with PBS, a DNA'-PEG-cells suspension $\left(200 \mu \mathrm{L}, 2.5 \times 10^{7}\right.$ cells $\left./ \mathrm{mL}\right)$ was injected into the space. The DNA' had a sequence that was complementary to the sequence of the DNA 
on the glass plate. After incubation for $10 \mathrm{~min}$ at RT, the cover glass and the silicone slices were carefully peeled off with gentle shaking while the substrate was fully immersed in PBS. After that, the substrate was further shaken in PBS gently to wash away any non-binding cells. It was important that the surface of the substrate not be exposed to the air-liquid interface, or the cells on the substrate would be detached at the interface. The substrate was then observed under a fluorescent upright microscope (BX51, Olympus, Tokyo, Japan) and a stereoscopic microscope (MZF LIII, Leica, Solms, Germany). 


\section{Results}

Contact angle on DNA-immobilized surface

An inkjet printer jets a small volume of ink onto a surface. The printed surface is expected to consist of a number of tiny islands formed by ink surrounded by a bare gold surface. The heterogeneities of the printed surfaces were evaluated from their contact angles using Cassie's equation. A polyA20-SH solution $(300 \mu \mathrm{g} / \mathrm{mL})$ was spotted onto a small area $(2.5 \times 2.0 \mathrm{~cm})$ on the gold surface one, two, four, or eight times by an inkjet printer. The contact angles on these surfaces are summarized in Fig. 1(a), as are contact angles of the gold surface and a surface homogeneously covered by polyA20-SH, which was prepared by immersing a gold surface in a polyA20-SH solution. The contact angles decreased with increasing times of spotting. Surface coverage percentage with polyA20-SH was estimated using Cassie's equation, as follows:

$\cos \theta_{\mathrm{c}}=\gamma_{1} \cos \theta_{1}+\left(1-\gamma_{1}\right) \cos \theta_{2}$

where $\theta_{1}, \theta_{2}$, and $\theta_{\mathrm{c}}$ are contact angles of the polyA20-SH immobilized surface, the surface of gold, and Cassie's contact angle (that is, the observed contact angle), respectively, and $\gamma_{1}$ is the surface fraction of the polyA20-SH-immobilized gold area. 
Surface coverage percentages were $37.4 \%, 68.4 \%, 92.7 \%$, and $99.8 \%$ for surfaces spotted one, two, four, or eight times, respectively, with polyA20-SH. In the following experiments, surfaces that were spotted four times with a DNA solution were used.

Fig. 1(b) shows the water contact angles of a gold surface and surfaces printed in DNA solutions. The water contact angles on the surfaces printed four times with a DNA-SH solution were around $42^{\circ}$ and decreased to around $32^{\circ}$ after hybridization with complementary DNA'. These results indicate that DNA-SH was effectively immobilized by printing using an inkjet printer and that the DNAs on the surface had the ability to hybridize with complementary DNA' molecules.

\section{FTIR-RAS analysis of the DNA-immobilized surface}

Fig. 2 shows FTIR-RAS spectra of surfaces painted with a polyA20-SH solution by an inkjet printer. There is a sharp peak at $1000-1250 \mathrm{~cm}^{-1}$, a broad peak at $1530-1780 \mathrm{~cm}^{-1}$, and a small peak a $1250-1550 \mathrm{~cm}^{-1}$, respectively assigned to the $\mathrm{P}=\mathrm{O}$ double bond of the phosphate group, the planar double bond of the nucleic acid base, and the glycoside bond of the deoxyribose. Fig. 2 also shows a spectrum of the polyA20 surface exposed to a solution containing complementary polyT20. The intensities of the peaks increased 
about 1.5 fold, indicating that polyA20 immobilized to the surface could hybridize with the complementary DNA specifically.

SPR measurements

The SPR apparatus was employed to study the interaction between DNA-SH immobilized on the surface and complementary DNA'-PEG-liposome. As shown in Fig. 3(a), when the gold surface was exposed to a polyA20-SH solution $(50 \mu \mathrm{g} / \mathrm{mL})$ for 60 min, the SPR angle increased $160 \mathrm{mDA}$, indicating the binding of polyA20-SH onto the gold surface through the Au-thiol reaction. The sensor surface was exposed to a BSA solution to inhibit nonspecific immobilization of the polyT20-PEG-liposome. When a suspension polyT20-PEG-liposome $(5 \mu \mathrm{g} / \mathrm{mL})$ was introduced to the sensor surface, a large increase in the SPR angle was observed. This result indicates that the polyT20-PEG-liposome was immobilized on the sensor surface. In contrast, only a small increase in SPR angle was observed when the polyA20 surface was treated with polyT20 in advance (Fig. 3(b)). These results indicated that polyT20-PEG-liposome specifically bound to the polyA20-immobilized surface through polyA-polyT hybridization. 
These results suggest that DNA-modified cells can be specifically immobilized on a surface carrying the complementary DNA' through DNA hybridization.

Immobilization of DNA-modified cells on a gold surface

Various patterns were drawn on glass plates using cells along the patterned DNA.

Solutions of DNA-SHs were printed by an inkjet printer onto a glass plate covered with a gold thin layer. DNA-SHs were immobilized onto the surface through the thiol-gold interaction. CCRF-CEM cells with DNA'-PEG-lipid, in which DNA' was complementary to the DNA sequence of the DNA-SHs on the surface, were applied to the surface to induce cell attachment through the DNA-DNA' hybridization.

Fig. 4(a) shows the logo mark of Kyoto University drawn using CCRF-CEM cells. The original logo mark shown in Fig. 4(b) was scanned and saved as a digital image and then printed with a SeqA'-SH solution $(300 \mu \mathrm{g} / \mathrm{mL}$ in PBS) on a gold surface by an inkjet printer. After washing of the glass plate, a suspension of SeqA-PEG-cells was applied and incubated for $10 \mathrm{~min}$ at RT. The logo mark clearly appeared as shown in Fig. 4(a) after unattached cells were removed by immersion of the plate in PBS and gentle agitation. 
Different kinds of cells also were immobilized onto certain different areas on a glass plate at the same time. Solutions of SeqA'-SH and SeqB'-SH $(300 \mu \mathrm{g} / \mathrm{mL}$, respectively) were applied to different ink cartridges, respectively, and printed onto certain areas (in the pattern of a dartboard target) by an inkjet printer, followed by immobilization on the area of the plate (Fig. 5). A mixed suspension of SeqA-PEG-cells (stained with red) and SeqB-PEG-cells (stained with green) $\left(2.5 \times 10^{7}\right.$ cells $/ \mathrm{mL}$, respectively) was applied to the plate as shown in Scheme 1. After incubation for 10 min at RT, unattached cells were removed by washing with PBS. The dartboard target pattern was observed under a fluorescence upright microscope, as shown in Fig. 5. SeqA-PEG-cells and SeqB-PEG-cells were attached on areas on which complementary SeqA' and SeqB' were printed, respectively. SeqB-PEG-SH cells were immobilized on the area indicated by ** in Fig. 5, which had been painted with SeqB'-SH. The area indicated by * in Fig. 5 was painted with SeqA'-SH and SeqB'-SH solutions, and both the SeqA-PEG-cells and SeqB-PEG-cells were immobilized on the area. The color of the area looked yellow macroscopically (left panel, Fig. 5).

A SeqA'-SH solution and a SeqB'-SH solution were applied to different ink cartridges, respectively. SeqA'-SH and SeqB'-SH solutions were printed to areas of five letters forming the word JAPAN, with different ratios of 1:0, 3:1, 1:1, 1:3, and 0:1, 
respectively. A mixed suspension of SeqA-PEG-cells (stained red) and SeqB-PEG-cells (stained green) was applied on the substrate and left for $10 \mathrm{~min}$. The five letters drawn by the cells are shown in Fig. 6(a). Cell ratios of red and green cells in each letter were determined using ImageJ software (National Institutes of Health, USA). The cell ratios changed, reflecting the compositions of SeqA'-SH and SeqB'-SH that were used to write each letter, as shown in Fig. 6(b). 


\section{Discussion}

Cell arrays have been prepared using various molecules as an adhesive to immobilize cells on specific areas on a substrate. For example, cell adhesive proteins, such as fibronectin and vitronectin, and antibodies have been employed [3-6]. Patterning of these factors and antibodies onto the substrate has been performed by means of micro-contact printing, inkjet printing, or photolithography $[7,8]$. Inkjet printing technique has been originally used for preparing patterning of fibronectin for cell pattering on substrate [15]. And this technique has been expanded to the patterning of neural cells by the use of collagen/poly-D-lysine and PEG [16]. Recently, mammalian cells could be 2- and 3-dimentionally patterned by projection of those cells to collagen surface by modified inkjet printer $[17,18]$. Some improvements are, however, needed before their use in biomedical studies. When adhesive proteins are used to immobilize cells, immobilizing different kinds of cells onto different areas on a plate is difficult because integrins are expressed on most adhesive cells. In addition, they cannot be applied to floating cells, such as lymphocytes. Antibodies can resolve some of these difficulties, but, as noted, they are expensive and can be difficult to acquire.

As demonstrated in this study, DNA is a suitable adhesive molecule for immobilizing different kinds of cells on a substrate, and an inkjet printer is a versatile 
way to draw complicated patterns. An inkjet printer in conjunction with DNAs can solve most of the problems mentioned above, including immobilizing floating cells, such as lymphocytes, as shown in Figs. 4, 5, and 6. A number of adhesive molecules can be prepared by changing nucleotide sequences, making it easy to immobilize different kinds of cells on different areas on a plate at the same time using DNAs with different sequences, as shown in Fig. 5. Immobilization of cell mixtures with different ratios also can be achieved, as shown Fig. 6 .

The contact angle of the gold surface is relatively large at $78^{\circ}$ (Fig. 1). It needs to be very small because the pure gold surface has a very high surface energy. The large contact angle indicates that it adsorbs various organic and non-organic molecules rapidly when it is exposed to the environment air. Application of polyA20-SH to the gold surface successfully decreased the contact angle by replacing the surface contaminants and was immobilized through the thiol-gold interaction. Surface coverage percentages by polyA20-SH were evaluated from the contact angles using Cassie's equation and were $37.4 \%, 68.4 \%, 92.7 \%$, and $99.8 \%$ for surfaces spotted one, two, four, or eight times, respectively, with a polyA20-SH solution. These results indicate that a solution ejected from a nozzle exists as droplets on the gold surface. 
Supplementary Fig. 1 shows droplets of a FITC-SeqA solution (FITC; fluorescein isothiocianate) on a gold surface. A FITC-SeqA solution was spotted once to an area of $2.5 \times 2.0 \mathrm{~cm}$ by an inkjet printer and the surface was observed under a microscope without washing. Each dot was formed by a drop of the FITC-SeqA solution ejected from a nozzle. The diameter of the dots was $38 \mu \mathrm{m}$. From the product information for the inkjet printer (by Canon), the minimum ink droplet volume was $1 \mathrm{pL}$. The diameter of the droplets was about $41 \mu \mathrm{m}$, which coincides well with the dot size of $38 \mu \mathrm{m}$ that was observed on the gold printed once in a FITC-SeqA solution.

We also examined the smallest diameter of a cell-immobilized area that our system could achieve. As Supplementary Fig. 2 shows, it was about $500 \mu \mathrm{m}$, as determined by a graphic software, but not by the inkjet printer, which had a minimum resolution of 9600 dpi (dots per inch). Graphic software with higher specification should be introduced to draw cell patterns with high resolution. Diameters of animal cells $(5-30 \mu \mathrm{m})$ and dots $(38 \mu \mathrm{m})$ formed on the gold surface by a SeqA-FITC solution suggest that single cell printing can in principle be achieved.

The pattern of a dartboard target was drawn with two kinds of cells and is shown in Fig. 5. Areas of cells stained with green and red are separated by lines without cells. We also attempted to immobilize two kinds of cells on areas without cell-free space 
(Supplementary Fig. 3(a)). A SeqA'-SH solution and a SeqB'-SH solution were printed on different areas at the same time. After washing away of the unreacted SeqA'-SH and SeqB'-SH, a mixed suspension of cells carrying SeqA-PEG-lipid cells and SeqB-PEG-lipid cells was applied. Supplementary Fig. 3(a) shows a fluorescence microscopic image of the marginal region of the two areas. Cells stained with red or green diffused into each other, and the two areas were not distinctly separated. This lack of distinction might be caused by mixing of the solutions of SeqA'-SH and SeqB'-SH at the marginal region, because the solutions were printed several times so that wet areas with different solutions came into contact and the two solutions diffused into each other. To solve this problem, a SeqA'-SH solution was printed in some areas, and after the surface was dried, a SeqB'-SH solution was applied to other areas. On the surface, red and green cells could be immobilized separately, as shown in Supplementary Fig. 3(b). 


\section{Conclusions}

DNAs are suitable adhesive molecules to immobilize various kinds of cells on a

substrate. An inkjet printer in conjunction with DNAs is a versatile method for drawing complicated patterns with cells. This method has various potential applications in biomedical studies, such as analysis of cell-cell interactions in regenerative medicine, drug screening in the pharmaceutical industry, and high-throughput assays in functional analyses of genes.

\section{Acknowledgments}

This study was supported in part by a Grant-in-Aid for Scientific Research (A) (No.

21240051) and Challenging Exploratory Research (No.21650118) from the Ministry of

Education, Culture, Sports, Science, and Technology (MEXT) of Japan. 
Table 1. Sequence of DNA for cell surface modification

\begin{tabular}{l|l}
\hline DNA & 5 \\
\hline polyA20 & HS-AAA AAA AAA AAA AAA AAA AA \\
polyT20 & HS -TTT TTT TTT TTT TTT TTT TT \\
SeqA & HS -TGC GGA TAA CAA TTT CAC ACA \\
SeqA' & HS-TGT GTG AAA TTG TTA TCC GCA \\
SeqB & HS-TAG TAT TCA ACA TTT CCG TGT \\
SeqB' & HS-ACA CGG AAA TGT TGA ATA CTA \\
\hline
\end{tabular}




\section{Figure captions}

Scheme 1. Schematic illustration of a method for cell immobilization on a pattern printed in DNA. (a) Immobilization of DNA with a specific sequence on the cell surface. DNA-PEG-DPPE was immobilized on the cell surface through the hydrophobic interaction between DPPE and the lipid bilayer of the cell membrane. (b) Printing a pattern in DNA'-SH with a complementary sequence of the DNA by an inkjet printer. The DNA-PEG-lipid-modified cells were applied to the substrate and immobilized on the pattern. (c) An inkjet printer used in this study, equipped with four ink cartridges to be loaded with different DNA'-SH solutions.

Figure 1. Water contact angles of surfaces printed in DNA solutions by an inkjet printer.

(a) Surface printed in a polyA20-SH solution one, two, four, or eight times using an inkjet printer and left for $60 \mathrm{~min}$. (b) Gold surface and surfaces printed in DNA solutions four times by an inkjet printer, and the surfaces after hybridization with complementary DNA'.

Figure 2. FTIR-RAS spectra of DNA-immobilized surfaces. (a) Bare gold surface, (b) polyA20 printed surface, and (c) surface with hybridized polyA20-polyT20. 
Figure 3. SPR profiles of the interaction between polyA20 immobilized on the surface and polyT20-PEG-liposome. (a) A polyA20-SH solution was introduced to the sensor surface (indicated by arrow (1)), and then PBS was infused to remove the polyA20-SH solution. A BSA solution was introduced to the surface for blocking (arrow (2)). Finally, a suspension of polyT20-PEG-liposome was introduced (arrow (3)). (b) A polyA20-SH solution was introduced to the exposed sensor surface (arrow (1)), and then PBS was infused to remove a polyA20-SH solution. A polyT20 solution was introduced to the sensor surface (arrow (2)). After a BSA solution was introduced to the surface for blocking (arrow (3)), a suspension of polyT20-PEG-liposome was introduced (arrow (4)).

Figure 4. Attachment of CCRF-CEM cells on a pattern printed in a SeqA'-SH solution by an inkjet printer. The logo mark of Kyoto University (panel a) was saved on a personal computer as an image and then printed on a gold surface in a SeqA'-SH solution. SeqA20-PEG-cells were applied to the surface (panel a). 
Figure 5. Fluorescence images of CCRF-CEM cells immobilized on a pattern printed in a SeqA'-SH and SeqB'-SH solution by an inkjet printer. Solutions of SeqA'-SH and SeqB'-SH were separately loaded into each ink cartridge. A pattern like a dartboard target was printed by these solutions. The center circle of the target was drawn in both SeqA'-SH and SeqB'-SH solutions. A mixed suspension of SeqA-PEG-cells (stained with PKH red) and SeqB-PEG-cells (stained with PKH green) (one to one by cell number) was seeded to the surface. Magnified images of areas marked by * and ** are shown on the right side.

Figure 6. Gradient immobilization of SeqA-PEG-cells (stained with PKH red) and SeqB-PEG-cells (stained with PKH green) on a plate. (a) Fluorescence images of CCRF-CEM cells immobilized on a pattern. Solutions of SeqA'-SH and SeqB'-SH were separately loaded into each ink cartridge. Five letters, JAPAN, were printed in both SeqA'-SH and SeqB'-SH solution by an inkjet printer. The spotted volume ratios of the solutions were controlled by a computer to $1: 0,3: 1,1: 1,1: 3$, or $0: 1$ by the volume for each letter of "JAPAN," respectively. A mixed suspension of SeqA-PEG-cells (stained with PKH red) and SeqB-PEG-cells (stained with PKH green) (one to one by the cell number) were seeded to the surface. (b) The cell compositions are plotted 
against surface ratios of SeqA' and SeqB' in letters. Ratios of SeqA-PEG-cells and SeqB-PEG-cells on the spots were determined from the fluorescence images using ImageJ software. The line is drawn for guiding the eye. 
(a)
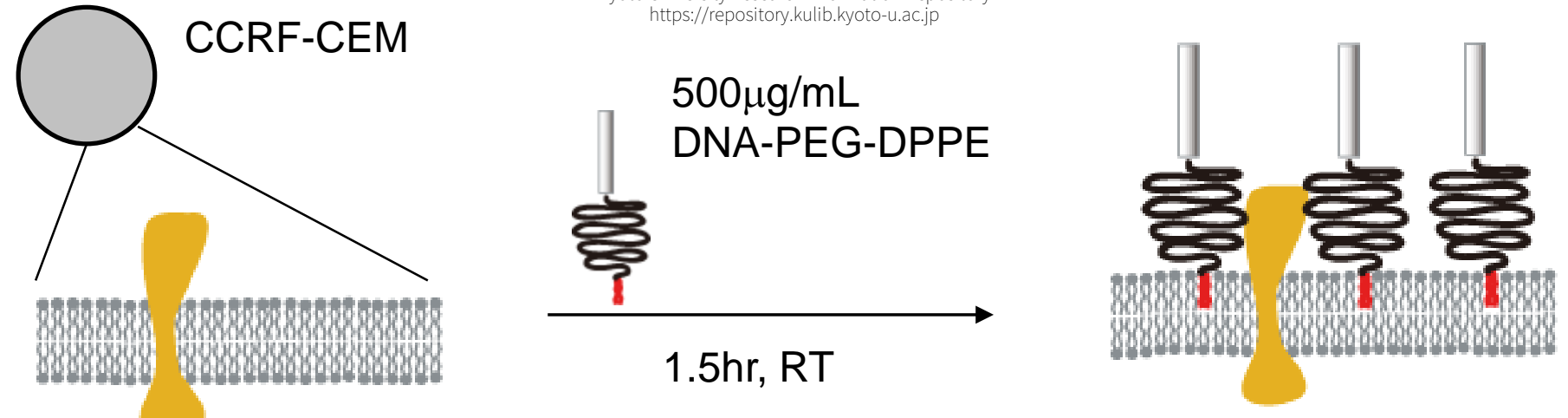

DNA-PEG-DPPE;

$$
\text { DNA Oot }
$$

(b)

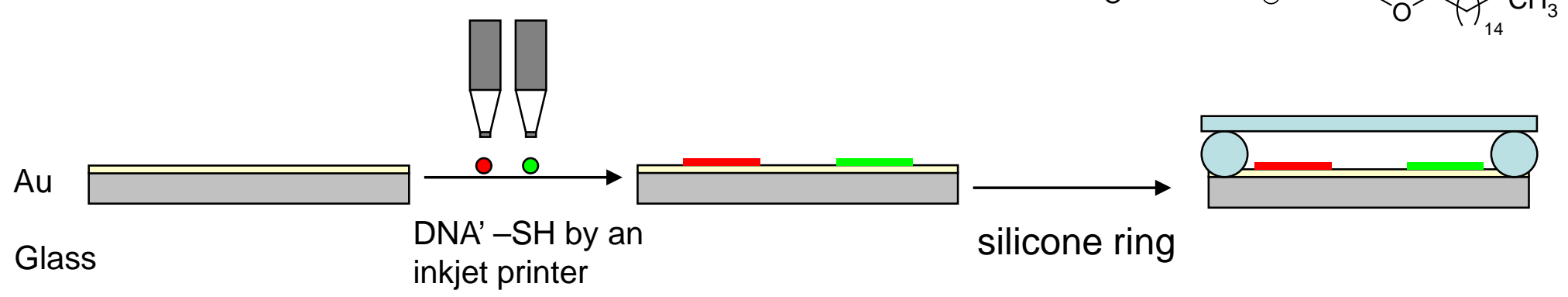

(c)
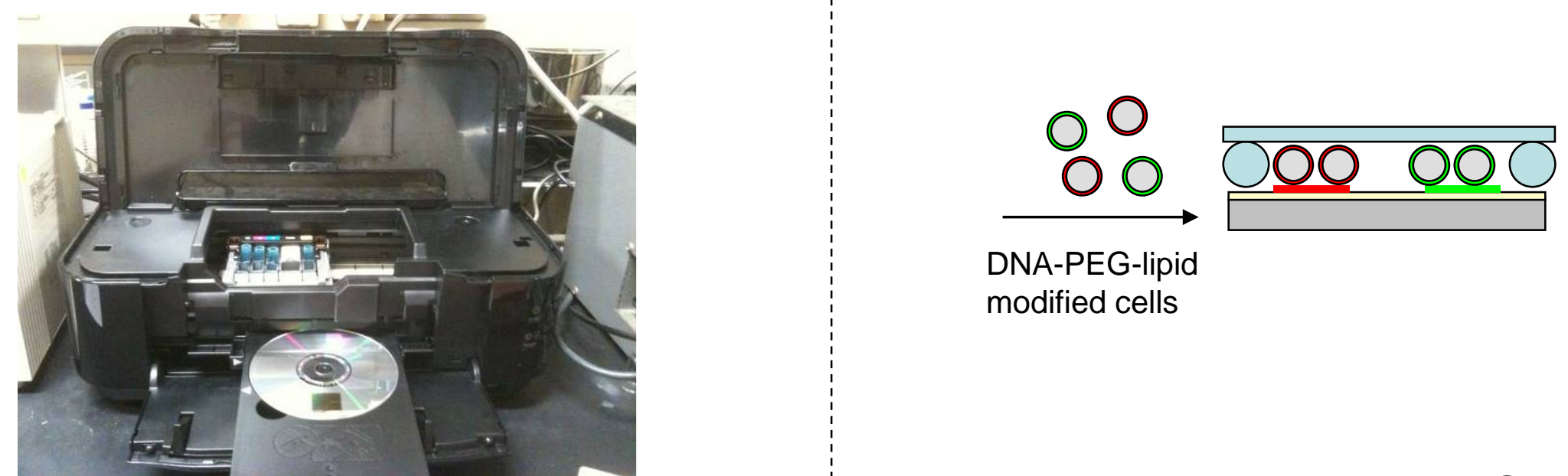

DNA-PEG-lipid modified cells 
(a)

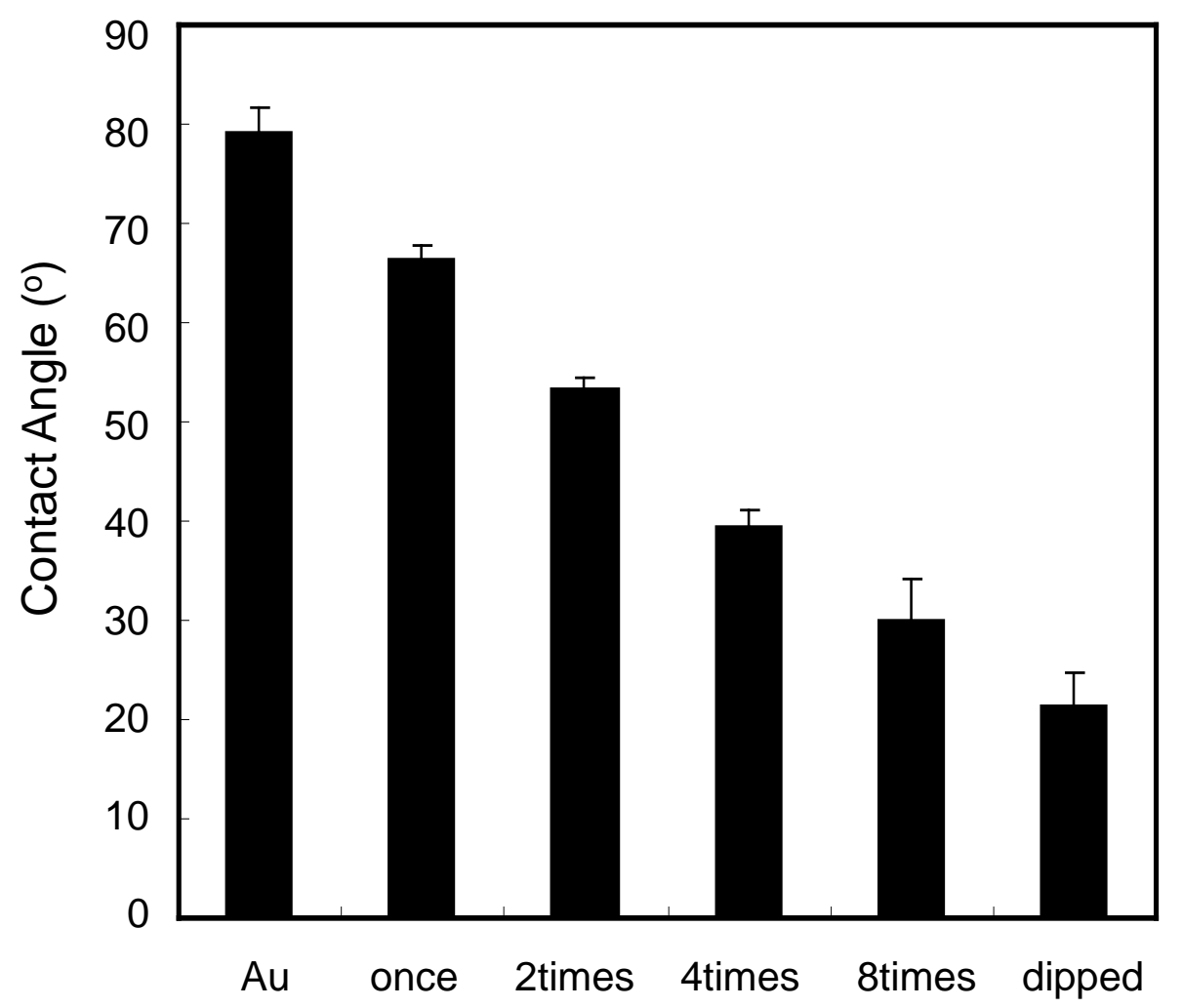

(b)

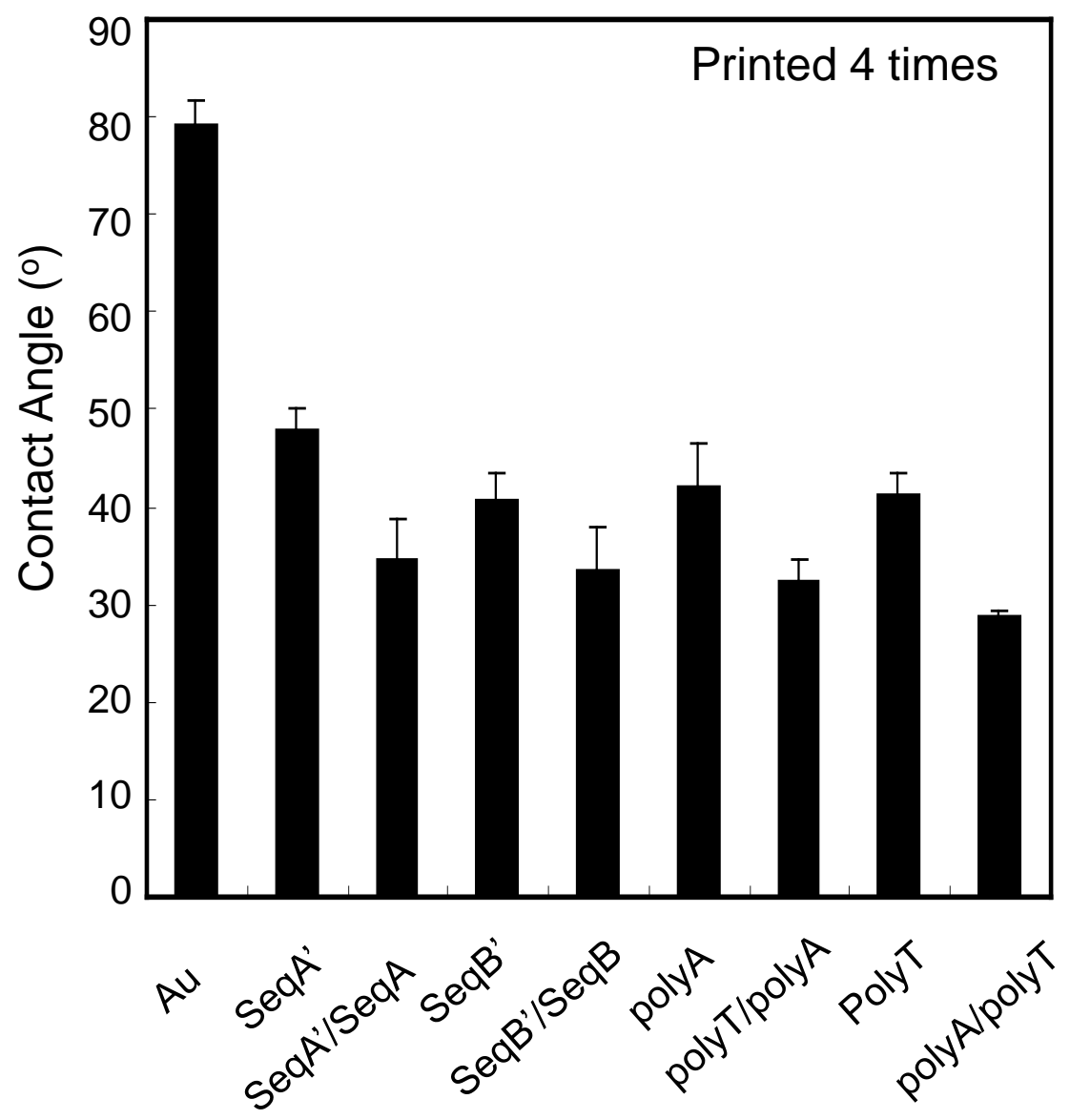

Figure 1 


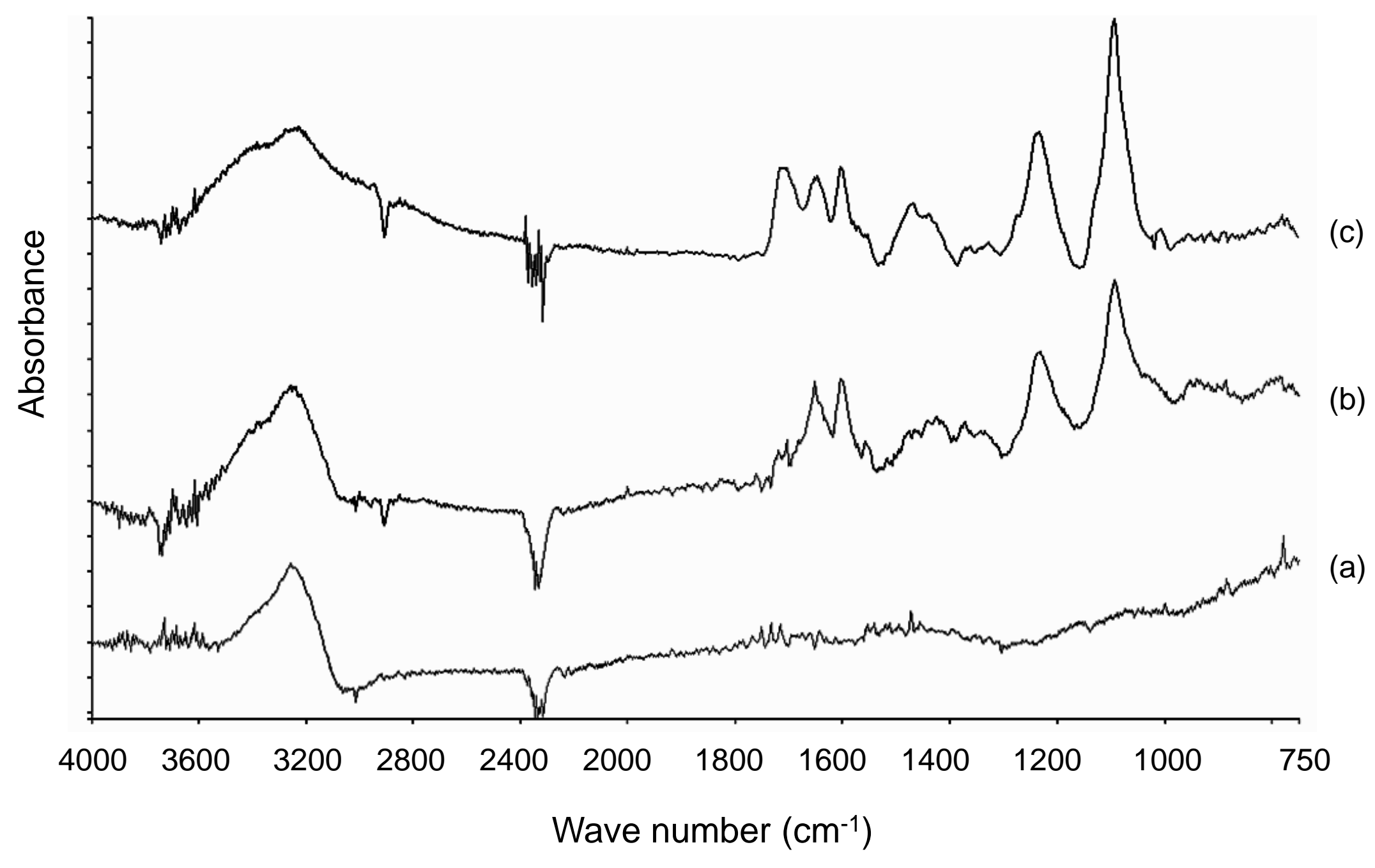

Figure 2 

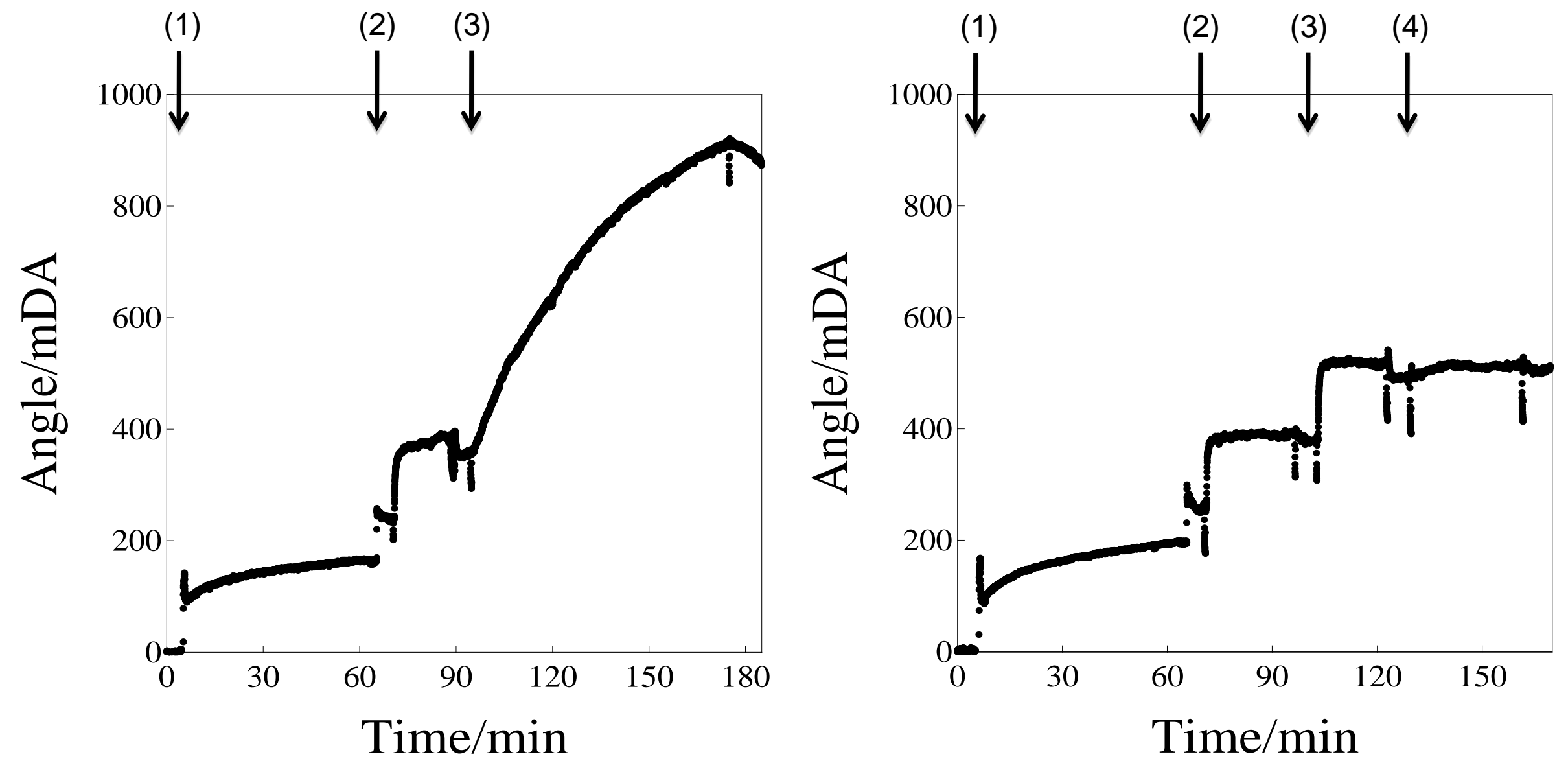

Figure 3 


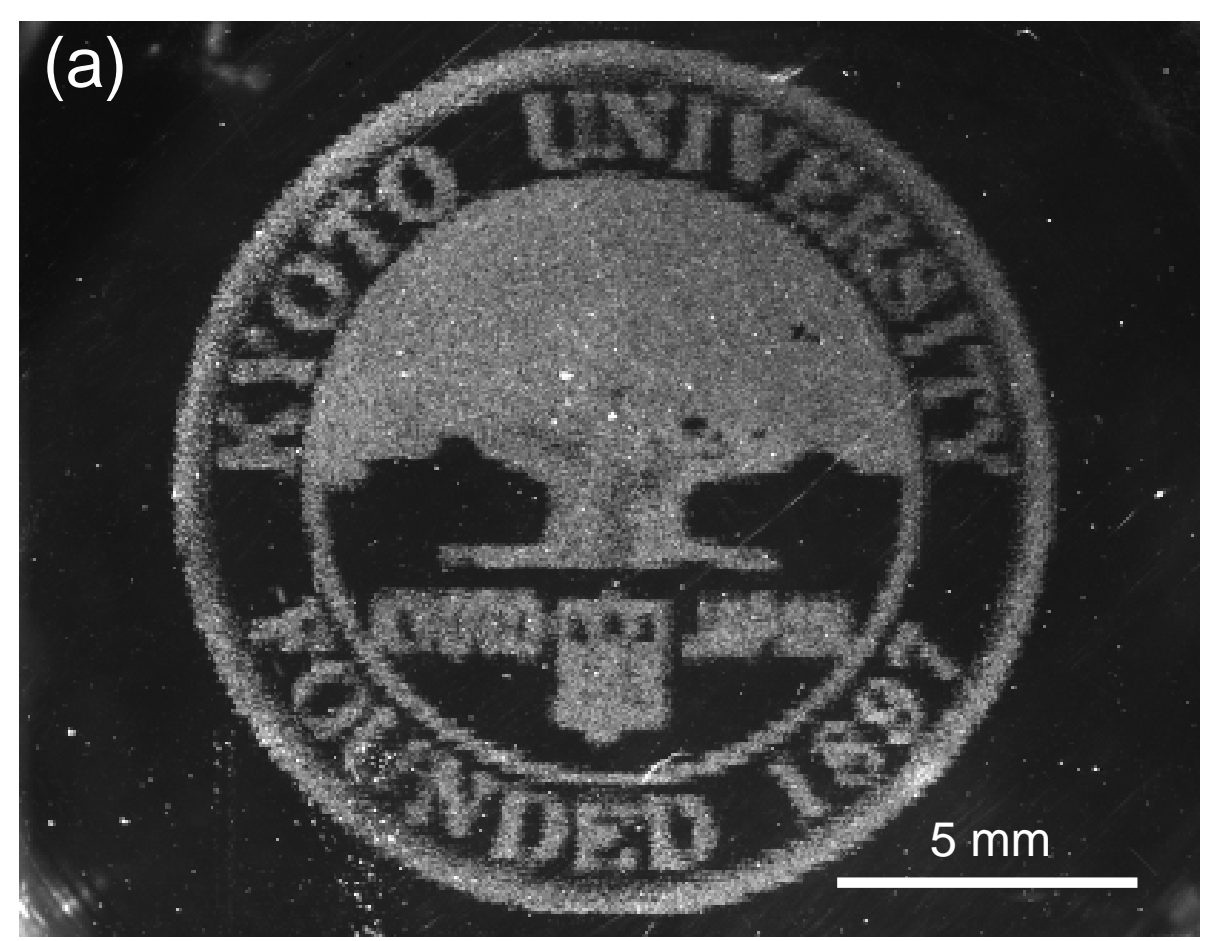

(b)

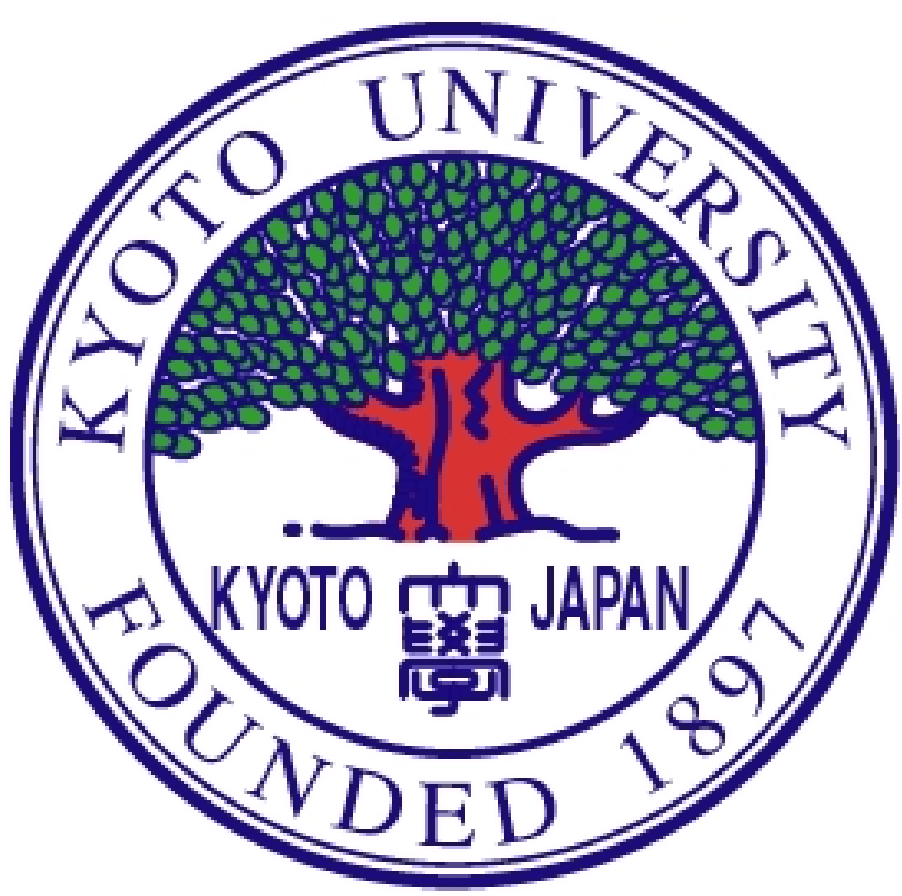

Figure 4 


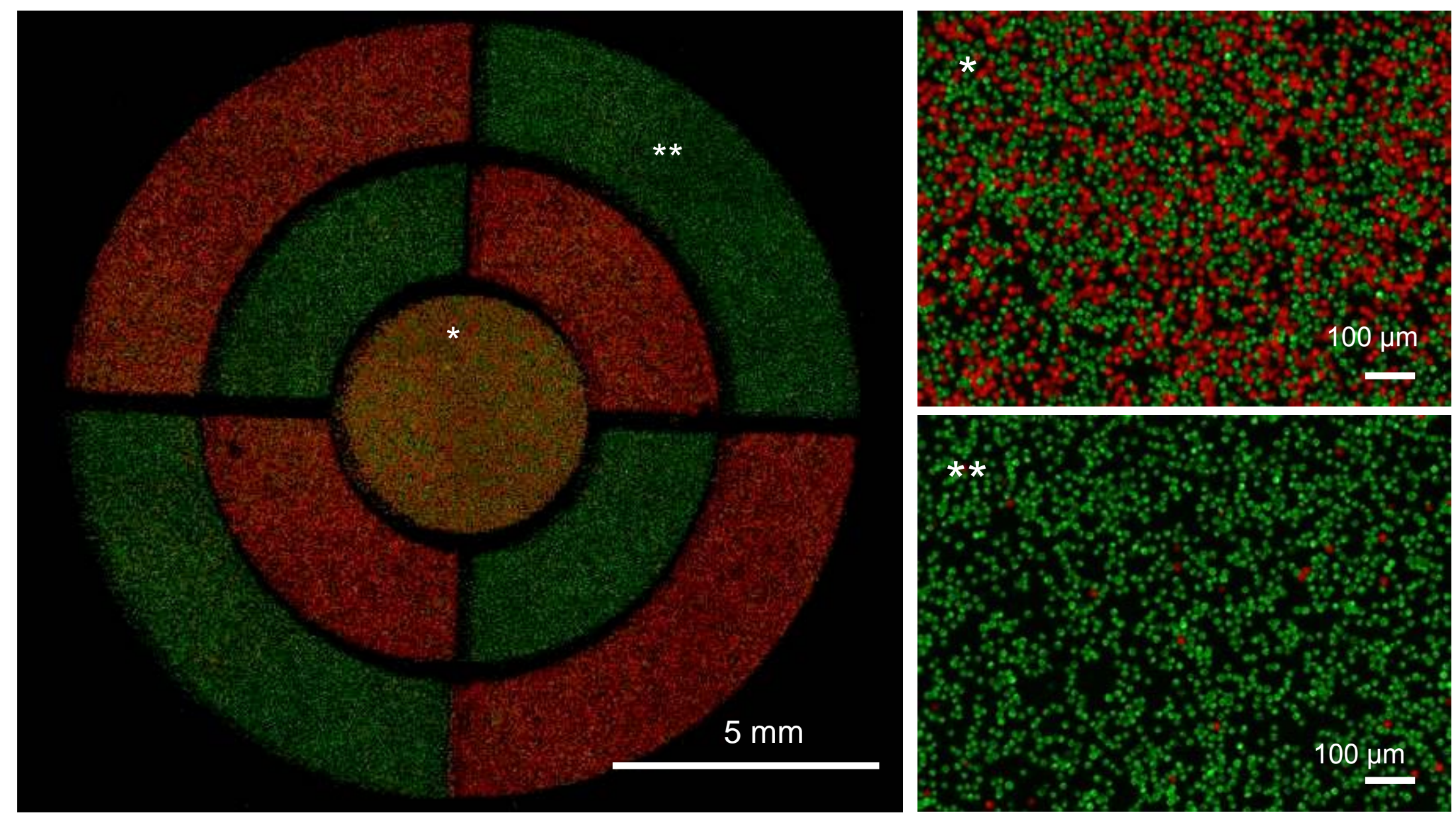

Figure 5 
(a)

SeqA'-SH':SeqB'-SH by volume
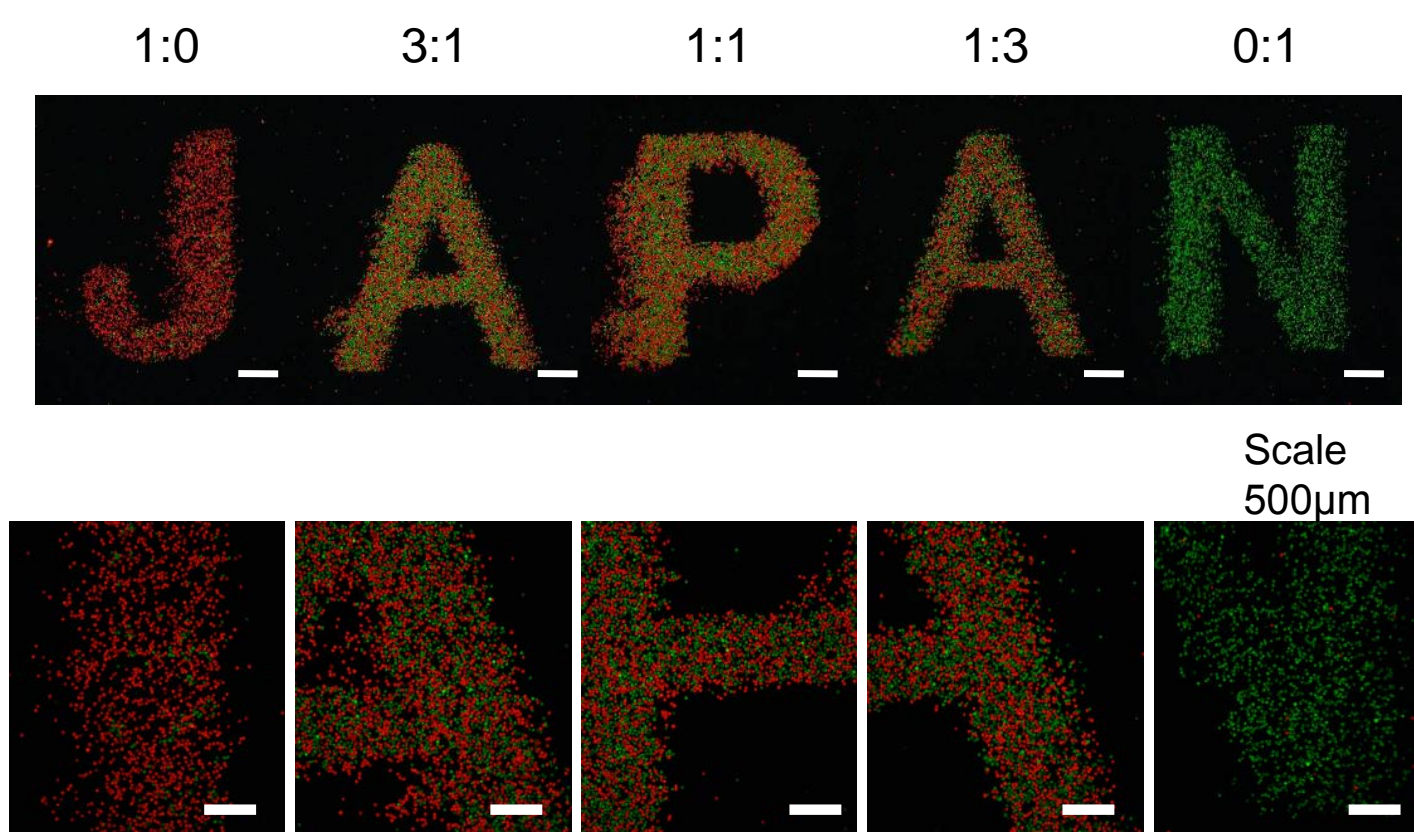

Scale

$500 \mu \mathrm{m}$

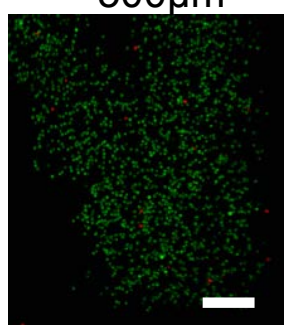

Scale

$200 \mu \mathrm{m}$ (b)

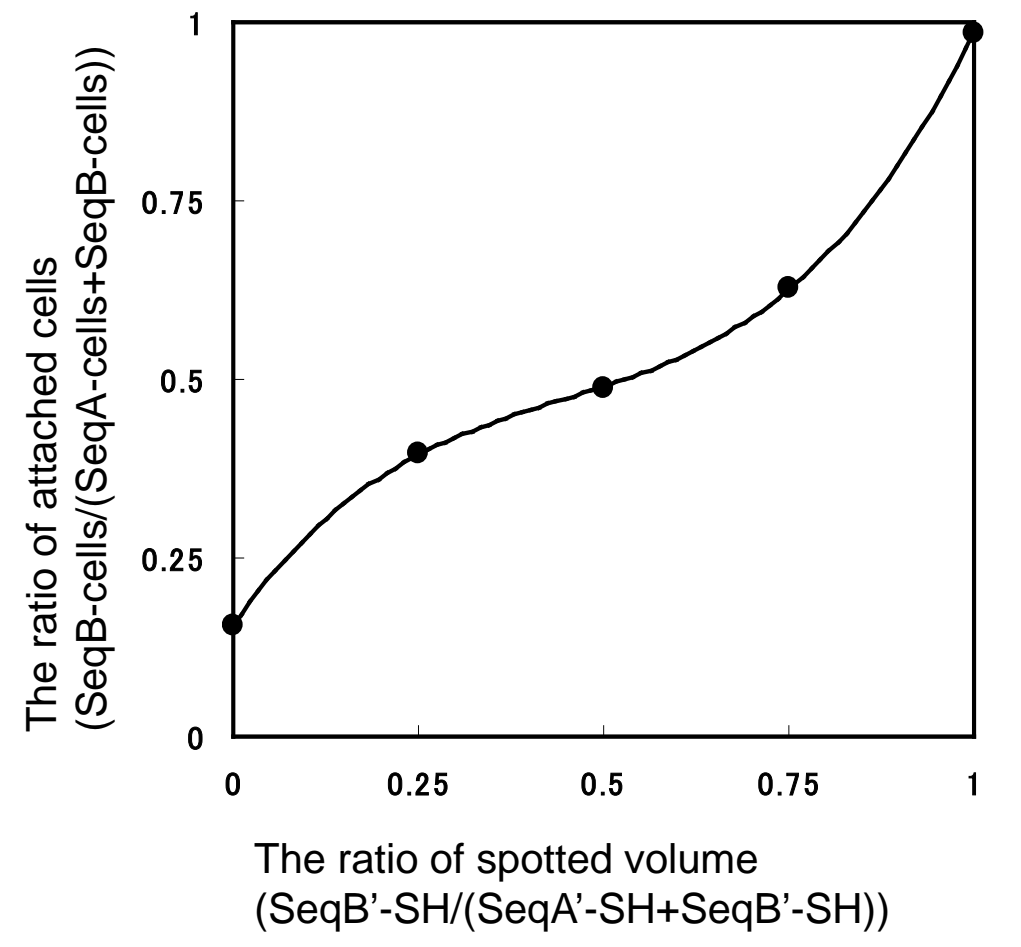

Figure 6 


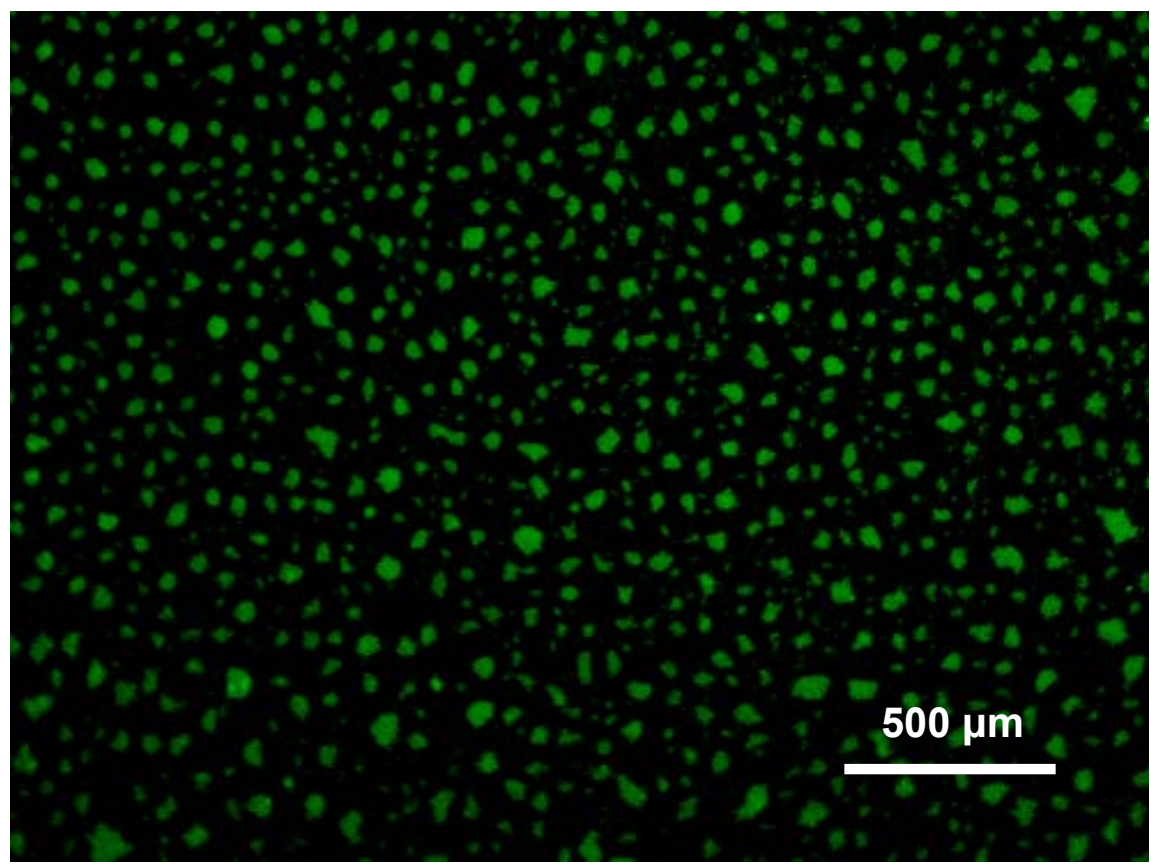

Supplementary Figure 1 


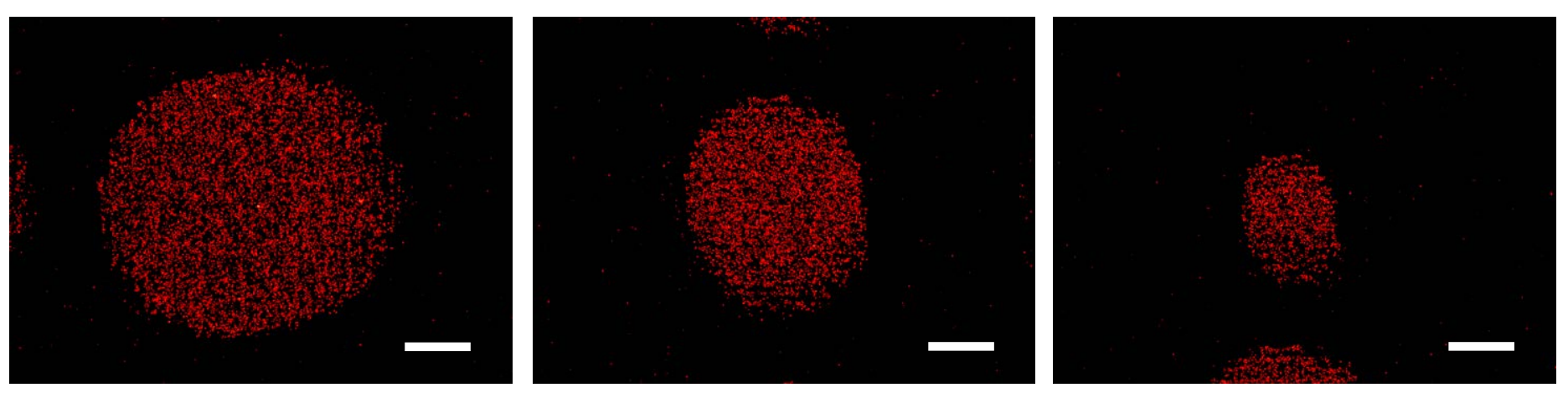

Scale: $500 \mu \mathrm{m}$

Supplementary Figure 2 
(a)

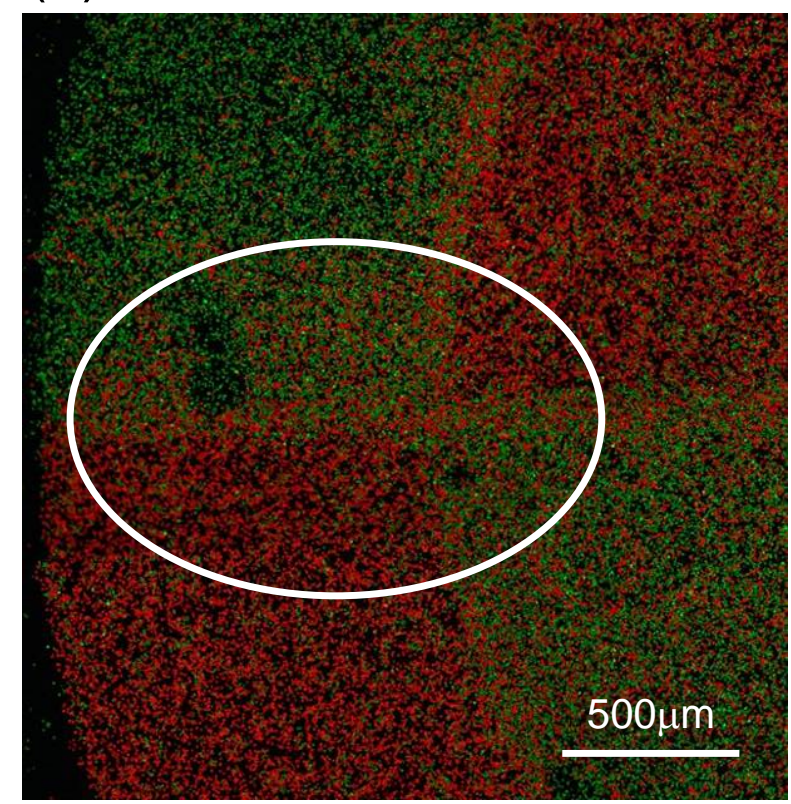

SeqA'-SH (b)

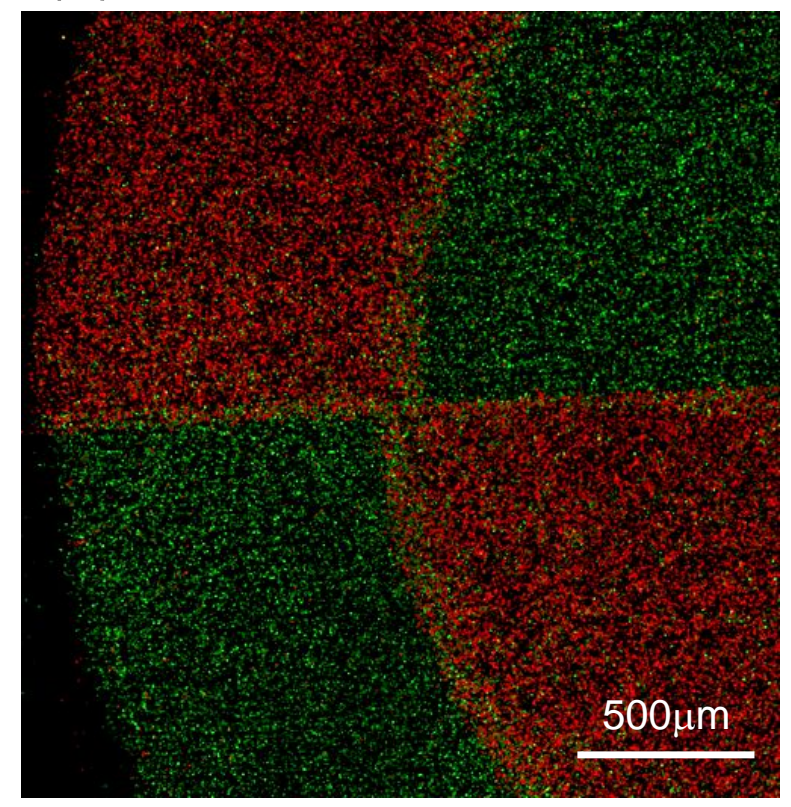

SeqB'-SH

SeqA'-SH 


\section{Supplementary data}

\section{Cells immobilized on patterns printed in DNA by an inkjet printer}

Kengo Sakurai $^{\mathrm{a}}$, Yuji Teramura ${ }^{\mathrm{b}}$, Hiroo Iwata $^{\mathrm{a}}$

a Department of Reparative Materials, Institute for Frontier Medical Sciences, Kyoto University, 53 Kawara-Cho, Shogoin, Sakyo-Ku, Kyoto, 606-8507, Japan

${ }^{\mathrm{b}}$ Radioisotope Research Center, Kyoto University, Yoshida-Konoe-Cho, Sakyo-ku, Kyoto, 606-8501, Japan

* Address correspondence and reprint requests to Hiroo Iwata, Ph.D.

E-mail: iwata@frontier.kyoto-u.ac.jp, PHONE/FAX: +81-75-751-4119

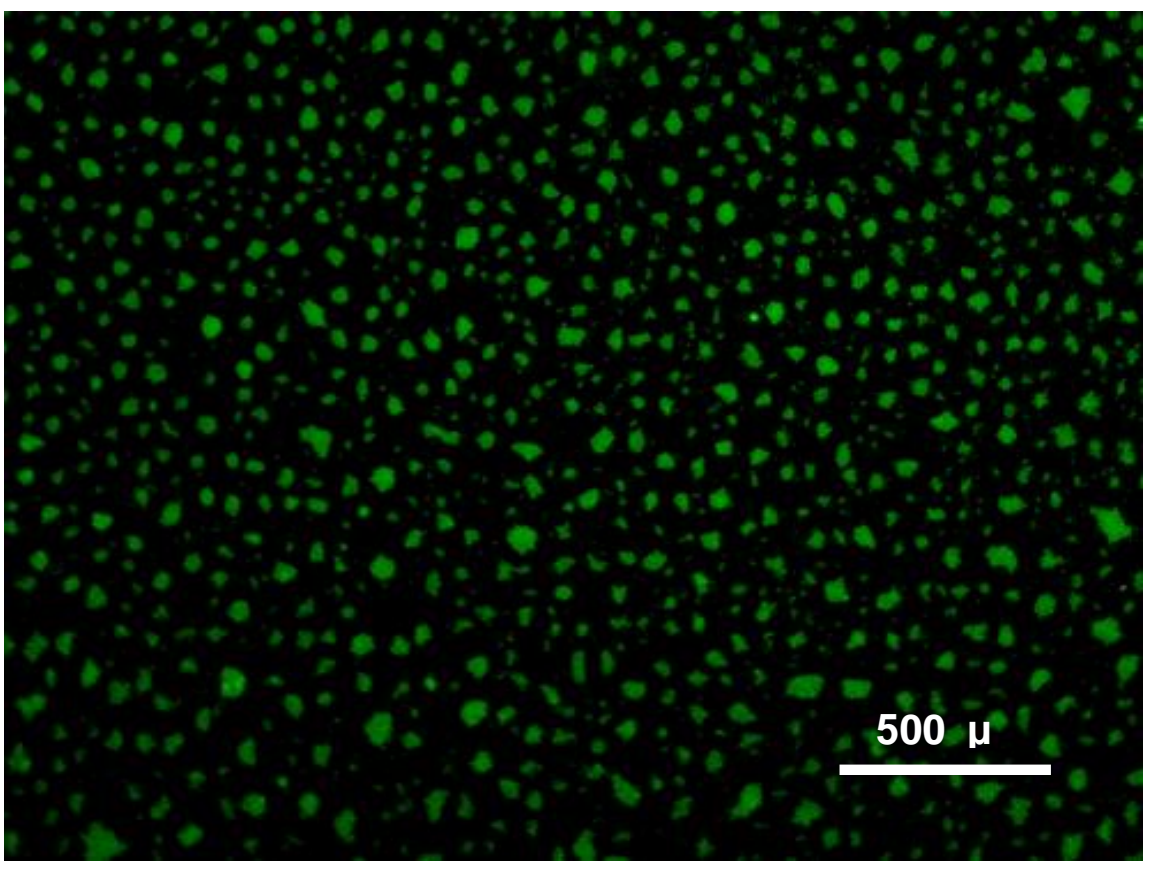

Supplementary Figure 1. Spots of a FITC-SeqA solution on a gold surface. A FITC-SeqA solution was applied to an area of $2.5 \times 2.0 \mathrm{~cm}$ once by an inkjet printer. Each dot was formed by a drop of the FITC-SeqA solution expelled by the inkjet printer. The surface without washing was observed under a fluorescence microscope. 

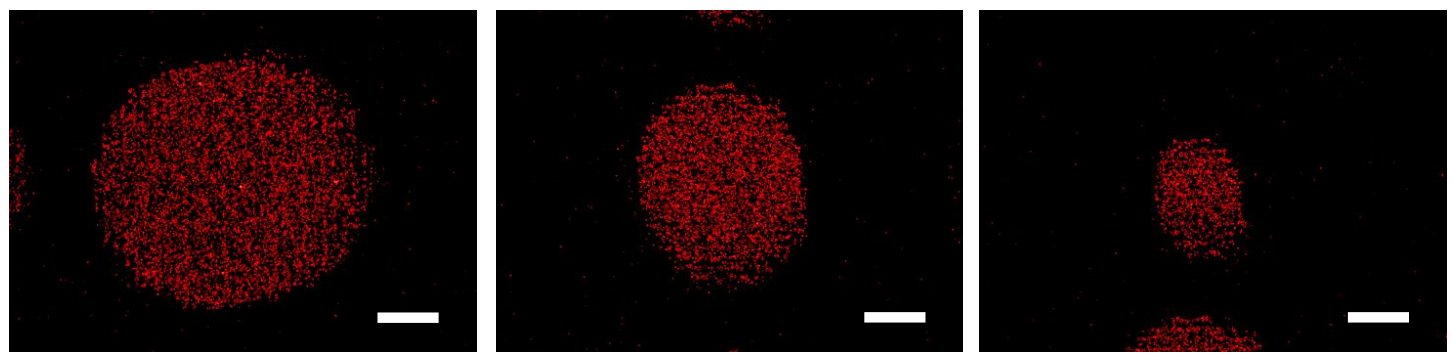

Scale: $500 \mu \mathrm{m}$

Supplementary Figure 2. Fluorescence images of cells (labeled with PKH red) on spots with diameters of $0.5 \mathrm{~mm}, 1.5 \mathrm{~mm}$, and $2.5 \mathrm{~mm}$. The spots that were $0.5 \mathrm{~mm}, 1.5 \mathrm{~mm}$, or $2.5 \mathrm{~mm}$ in diameter were drawn on the gold surface by an inkjet printer using Rakuchin CD Direct Print for Canon. The smallest diameter of a spot depends on the ability of the software to draw it.

(a)

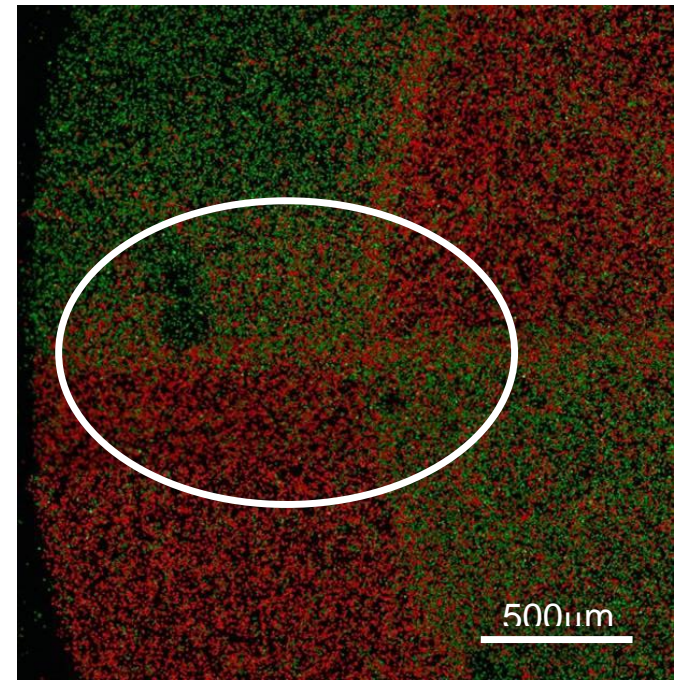

SeqA'-SH (b)

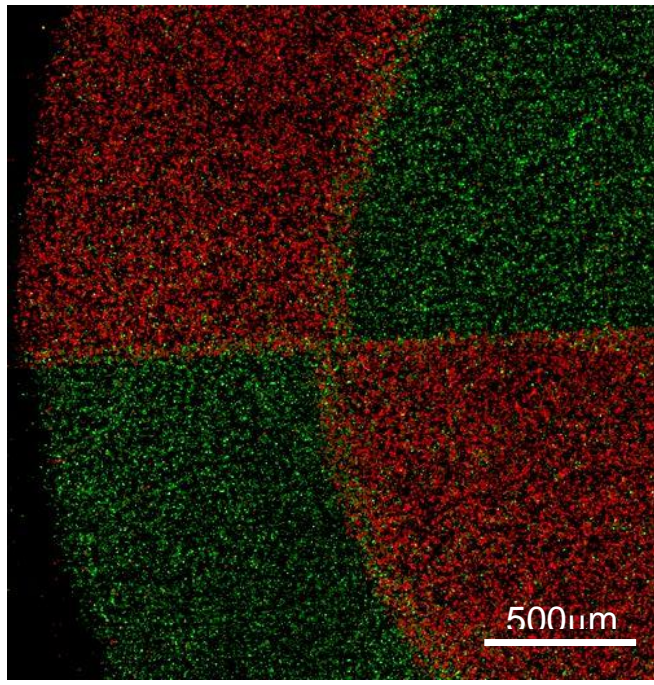

SeqB'-SH

SeqA'-SH

Supplementary Figure 3. Effect of print sequences on clarity of boundary regions. Solutions of SeqA'-SH and SeqB'-SH were separately loaded into each ink cartridge. (a) A pattern was drawn in SeqA'-SH and SeqB'-SH solutions at the same time. (b) A pattern was drawn in a SeqA'-SH solution. After the solution on the surface was dried, the other pattern was drawn in a SeqB'-SH solution. The mixed suspension of SeqA-PEG-cells (PKH red) and SeqB-PEG-cells (PKH green) was applied to the plates. In the case of (a), there were mixed regions where red and green cells co-existed. In the case of (b), the boundary regions were clearer than those of (a). 


\section{References}

[1] Hung PJ, Lee PJ, Sabounchi P, Lin R, Lee LP. Continuous perfusion microfluidic cell culture array for high-throughput cell-based assays. Biotechnol Bioeng 2005;89:1-8.

[2] Ziauddin J, Sabatini DM. Microarrays of cells expressing defined cDNAs, Nature 2001;411:107-110.

[3] Yue C, Oelke M, Paulaitis ME, Schneck JP. Novel cellular microarray assay for profiling T-cell peptide antigen specificities. J Proteome Res 2009;9:5629-5637.

[4] Yamazoe H, Iwata H. Cell microarray for screening feeder cells for differentiation of embryonic stem cells. J Biosci Bioeng 2005;100:292-296.

[5] Peterson AW, Halter M, Tona A, Bhadriraju K, Plant AL. Surface plasmon resonance imaging of cells and surface-associated fibronectin. BMC Cell Biology 2009;10:1-17.

[6] Yamauchi F, Okada M, Kato K, Jakt LM, Iwata H. Array-based functional screening for genes that regulate vascular endothelial differentiation of Flk1-positive progenitors derived from embryonic stem cells. Biochim Biophys Acta 2007; 1770:1085-1097.

[7] Hu J, Shi J, Zhang F, Lei L, Li X, Wang L, et al. High resolution and hybrid patterning for single cell attachment. Microelectronic Engineering 2010;87:726-729. 
[8] Ingham C, Bomer J, Sprenkels A, van den Berg A, de Vos W, van Hylckama Vlieg

W. High-resolution microcontact printing and transfer of massive arrays of

microorganisms on planar and compartmentalized nanoporous aluminium oxide. Lab

Chip, 2010;10:1410-1416.

[9] Miyazaki H, Maki T, Kato K, Iwata H. Surface-displayed antibodies as a tool for simultaneously controlling the arrangement and morphology of multiple cell types with microscale precision. ACS Appl Mater Interfaces 2009;1:53-55.

[10] Teramura Y, Chen H, Kawamoto T, Iwata H. Control of cell attachment through polyDNA hybridization. Biomaterials 2010;31:2229-2235.

[11] Teramura Y, Iwata H. Bioartificial pancreas Microencapsulation and conformal coating of islet of Langerhans. Adv Drug Deliv Rev 2010;62:827-840.

[12] Teramura Y, Iwata H. Cell surface modification with polymers for biomedical studies. Soft Matter 2010;6:1081-1091.

[13] Teramura Y, Kaneda Y, Iwata H. Islets-encapsulation with ultra-thin layer-by-layer membranes of poly(vinyl alcohol) through poly(ethylene glycol)-lipids anchored to cell surface. Biomaterials 2007;28:4818-4825. 
[14] Hirata I, Morimoto Y, Murakami Y, Iwata H, Kitano E, Kitamura H et al. Study of complement activation on well-defined surfaces using surface plasmon resonance.

Colloids Surf B 2000;18: 285-292.

[15] Klebe RJ. Cytoscribing: a method for micropositioning cells and the construction of two- and three-dimensional synthetic tissues. Exp Cell Res 1988;179:362-373.

[16] Sanjana NE, Fuller SB. A fast flexible ink-jet printing method for patterning dissociated neurons in culture. J Neurosci Methods 2004;136:151-163.

[17] Wilson WC Jr, Boland T. Cell and organ printing 1: protein and cell printers. Anat Rec A Discov Mol Cell Evol Biol 2003;272:491-496.

[18] Boland T, Mironov V, Gutowska A, Roth EA, Markwald RR. Cell and organ printing 2: fusion of cell aggregates in three-dimensional gels. Anat Rec A Discov Mol Cell Evol Biol. 2003;272:497-502. 